The decreased incidence of potentially autogenous Gramnegative bacillary infections may well be unrelated to the change in ward architecture, but the criteria used to classify cross-infection meant that some of the intestinal type of infections labelled autogenous were in fact cross-infections. As expected, the incidence of definite staphylococcal autogenous infection remained substantially the same over the four years of observation.

\section{References}

Henderson, R. J., and Williams, R. E. O. (1963). Fournal of Clinical Pathology, 16,452

Moore, B. (1963). In Infection in Hospitals, ed. R. E. O. Williams and R. A. Shooter, p. 7. Oxford, Blackwell Scientific.

Nuffield Provincial Hospitals Trust (1955). Studies in the Functions and Design of Hospitals. London, Oxford University Press.

Smylie, H. G. (1960). M.D. Thesis, Aberdeen University.

Smylie, H. G. (1960). M.D. Thesis, Aberdeen University. Hospital Infection: Causes and Prevention, 2nd edn. London, Lloyd-Luke.

\title{
Ward Design in Relation to Postoperative Wound Infection: Part II
}

\author{
A. I. G. DAVIDSON， H. G. SMYLIE，A. MACDONALD， G. SMITH
}

British Medical fournal, 1971, 1, 72-75

\section{Summary}

A detailed investigation has been carried out into the behaviour of wounds after 1,000 general surgical operations, about equal numbers of patients having been studied in two different ward and operating theatre environments. The wound sepsis rate was reduced after transfer to the new type of ward. It is concluded that features of the new ward environment were responsible for the observed fall in the incidence of cross-infection.

\section{Introduction}

At present, despite a considerable volume of published work, there would appear to be neither accepted criteria for the definition of wound infection nor any clear classification based on aetiological factors. The significance of wound sepsis is related both to its frequency and severity and to its probable source. This paper describes briefly some of the findings in a detailed investigation of 1,000 patients studied in two ward and operating theatre environments.

\section{Terminology}

In any consideration of the incidence of wound infection it is essential to define the terms used.

\section{TYPE OF OPERATIVE PROCEDURE}

Infection has been defined as the "deposition and multiplication of organisms in the tissues" (Williams et al., 1966). Exogenous wound contamination depends both on the patient's environment in the operating theatre and in the ward and on the extent of the operation undergone. Endogenous contamination is, however, a feature of particular types of operation. Operations can therefore be subdivided into two main groups: (a) clean operations-procedures where no source of infection is normally encountered, the tissues

University of Aberdeen

A. I. G. DAVIDSON, CH.M., F.R.C.S.ED., Senior Registrar in Surgery H. G. SMYLIE, M.D., M.R.C.PATH., Senior Lecturer in Bacteriology A. MACDONALD, M.A., M.D., Professor of Bacteriology G. SMITH, CH.M., F.R.c.s., Regius Professor of Surgery being sterile when incised-for example, herniorrhaphy, mastectomy, thyroidectomy, etc.; and (b) potentially dirty operations-procedures with an existing source of contaminationfor example, biliary, intestinal, urological, etc.

Both types of operation are at risk from exogenous contamination, but endogenous contamination is an especial risk in the potentially dirty group.

\section{DEGREES OF WOUND INFECTION}

It is obviously misleading to include under the same heading a severe cellulitis with abscess formation, resulting in complete disruption of a wound, and a minor degree of stitch-hole sepsis. Wound infections were therefore divided into two main groups, all being classified by the same person (A.I.G.D.): (a) major infection-severe sepsis with pus formation requiring drainage, frequent dressings, and almost invariably a prolonged hospital stay followed by outpatient attention until final healing; and $(b)$ minor infection-a slight purulent discharge, transient cellulitis, or isolated stitch-hole sepsis, with no significant increase in morbidity.

For inclusion as an infected wound of either group the clinical classification was supported by a positive culture of pathogenic organisms from swabs taken of the wound discharge. There are advantages to this type of subdivision in that the effects of major infections could be considered separately. In this study only organisms of known pathogenicity were recorded as significant. These included Staphylococcus pyogenes, Escherichia coli, Streptococcus faecalis, and Proteus. Staph. pyogenes was considered alone, but the remaining pathogens were taken together and described as "intestinal organisms," the term being simply collective to describe the group and not necessarily implying an origin from the intestinal tract. Mixed growths of organisms of this group were often found, pure cultures being the exception. Phage typing of Staph. pyogenes was carried out when this organism was grown. Some phage subcultures, however, were lost, this aspect of the investigation being deficient, especially in the early months.

\section{CLASSIFICATION OF WOUND INFECTIONS}

In the past a problem in any discussion of postoperative wound infection has been whether the infections have arisen from bacterial contamination in the operating theatre or from cross-infection in the ward. A detailed study of the bacteriological environment of patients during operation, together with a complete follow-up of the subsequent behaviour of the 
wound, has suggested a classification of wound sepsis based on possible sources of bacterial contamination (Davidson, 1969).

Primary infections-those cases where infection was evident at the time of first inspection of the wound, there being no obvious contributory factor (see Secondary infections). Such infections were thought to be the result of either endogenous contamiration during operation or, less often, bacterial contamination from some part of the operating theatre environment. In this group infections with Staph. pyogenes were included, the patient being a carrier of the same phage type of organism at the time of operation. By definition all primary infections were assumed to have resulted from contamination with organisms during the operative procedure, these organisms being endogenous or exogenous in origin.

Secondary infections-those Staph. pyogenes infections where a contributory factor was present and the bacteriological evidence supported the significance of this factor. The group was made up of those infections which seemed to arise in the ward as a result of cross-infection. Secondary infections were considered to arise in four different ways. (1) If, at the time of first inspection of the wound (on account of drain shortening or removal, plaster allergy, wound discomfort, suspected infection, excessive soakage, or aspiration of a haematoma), healing appeared satisfactory and no pathogens were grown from the wound swab, then development of sepsis in the wound subsequent to such manoeuvres allowed the infection to be classified as secondary. (2) Ischaemia or necrosis of the wound edges occasionally occurred after such operations as mastectomy, where skin flaps are made. Though initially sterile, such areas tended to form a focus for secondary infection. (3) The site of emergence of a drain through the skin is an obvious site of potential infection. Drain-site sepsis may occur alone or in association with infection in the wound. Where drain-site sepsis was a precursor of wound sepsis, the same phage type of organism being cultured from both drain site and wound, then the infection was classified as secondary. (4) A secondary staphylococcal infection was said to occur when initial cultures from an infected wound gave a growth of some other organisms (usually of the intestinal group) but subsequently Staph. pyogenes was isolated.

\section{Environment}

A description of the ward environments during the four years of the investigation was given in Part I. In the old environment the operating theatre was one of a block of two in open communication, separated only by an area used for scrubbing up and laying trolleys. Ventilation was by a slow continuous exchange system giving a rate of less than two air changes per hour (Smylie, 1960). In the new unit the theatre was one of a suite of four, ventilation being by a continuous exchange positive-pressure (plenum) system achieving a rate of 10-20 air changes per hour.

\section{Methods}

More than 1,070 patients were studied. Data were incomplete for several, and a total of 1,000 patients made up the group for final analysis. The requirements for inclusion of a patient in this investigation were that the operation be carried out in the unit operating theatre, and that the operation itself had to involve an incision through clean prepared skin suitable for primary closure. No procedure obviously dirty from the start was included-for example, incision of abscess, operations inside the mouth or in the anal canal-neither was any operation performed an an outpatient, nor any operation carried out by a unit surgeon in a different operating theatre. At the end of operation dressings were applied, no wound included in the study being left uncovered until removal of sutures. Bacteriological methods were those described in Part I.

During the postoperative period a full description of the progress of each wound was recorded. In the uncomplicated case dressings were left intact until suture removal, the state of the wound then being recorded and a bacteriological swab taken of the suture line. If dressings were disturbed for any reason the state of the wound was recorded and a swab taken of the suture line. Similarly, drain sites were observed and swabbed at the time of shortening and removal of drains.

A total of 493 patients were investigated during 1965-6, when the professorial surgical unit occupied the old environment, a further 507 being studied after the unit had moved to the new wing in September 1966. In the operating theatre, bacteriological data obtained for every patient included nasal and skin carrier state, the efficacy of skin preparation, settle plates open during operating, cultures of the subcutaneous tissues and suture line at the end of operation, and finger and mask plates from every scrubbed member of the operating team. An analysis of these findings has been described, no difference being found between possible bacteriological hazards in the two operating theatre environments (Davidson, 1969; Davidson et al., 1970).

\section{Results}

In this group of 1,000 patients a total of 145 operations $(14.5 \%)$ were complicated by some degree of wound infection (Table I). Of these $67(6.7 \%)$ gave a growth of Staph. pyogenes, the remainder being associated with some other organism. Only 79 infections $(7.9 \%)$ could be classified as major, the other 66 $(6.6 \%)$ being examples of minor sepsis. It will be seen that there was a fall in the incidence of postoperative wound sepsis after moving to the new environment, the most pronounced fall being in the incidence of major infections with Staph. pyogenes (Table I).

A gross analysis has limited value if consideration of the spectrum of operations is not included. A subdivision into clean and potentially dirty procedures at least gives two distinct groups, each identifiable by factors inherent in the performance of the operation. The postoperative wound infection rate was found to be $48 / 669(7.2 \%)$ after clean operations, but much higher at $97 / 331(29.3 \%)$ in the potentially dirty group (Tables II and III). These tables also show the incidence for all infections, staphylococcal infections, and major staphylococcal infections to be greater after potentially

TABLE I-Overall Incidence of Wound Infection with Staph. pyogenes and Intestinal Organisms

\begin{tabular}{|c|c|c|c|c|c|c|}
\hline \multirow[t]{2}{*}{ Ward } & \multirow{2}{*}{$\begin{array}{l}\text { No. of } \\
\text { Patients }\end{array}$} & \multirow{2}{*}{$\begin{array}{l}\text { Wound } \\
\text { Infections }\end{array}$} & \multicolumn{2}{|c|}{$\begin{array}{l}\text { Staph. pyogenes } \\
\text { Infection }\end{array}$} & \multicolumn{2}{|c|}{$\begin{array}{c}\text { Intestinal Organism } \\
\text { Infection } \\
\end{array}$} \\
\hline & & & All & Major & All & Major \\
\hline $\begin{array}{l}\text { Old } \\
\text { New }\end{array}$ & $\begin{array}{l}493 \\
507 \\
\end{array}$ & $\begin{array}{l}96(19 \cdot 5 \%) \\
49(9 \cdot 7 \%) \\
\end{array}$ & $\begin{array}{l}42(8.5 \%) \\
25(4.9 \%) \\
\end{array}$ & $\begin{array}{l}30(6 \cdot 1 \%) \\
10(2 \cdot 0 \%) \\
\end{array}$ & $\begin{array}{l}54(11 \cdot 0 \%) \\
24 \quad(4.7 \%) \\
\end{array}$ & $\begin{array}{l}24(4.9 \%) \\
15(3.0 \%) \\
\end{array}$ \\
\hline Total & 1,000 & $145(14.5 \%)$ & $67(6.7 \%)$ & $40(4 \cdot 0 \%)$ & $78 \quad(7 \cdot 8 \%)$ & $39(3.9 \%)$ \\
\hline
\end{tabular}

TABLE II-Incidence of Wound Infection with Staph. pyogenes and Intestinal Organisms after Clean Operations

\begin{tabular}{|c|c|c|c|c|c|c|}
\hline \multirow[t]{2}{*}{ Ward } & \multirow{2}{*}{$\begin{array}{l}\text { No. of } \\
\text { Patients }\end{array}$} & \multirow{2}{*}{$\begin{array}{l}\text { Wound } \\
\text { Infections }\end{array}$} & \multicolumn{2}{|c|}{$\begin{array}{l}\text { Staph. pyogenes } \\
\text { Infection }\end{array}$} & \multicolumn{2}{|c|}{$\begin{array}{l}\text { Intestinal Organism } \\
\text { Infection }\end{array}$} \\
\hline & & & All & Major & All & Major \\
\hline $\begin{array}{l}\text { Old } \\
\text { New }\end{array}$ & $\begin{array}{l}314 \\
355\end{array}$ & $\begin{array}{l}29(9.2 \%) \\
19(5.4 \%)\end{array}$ & $\begin{array}{l}16(5 \cdot 1 \%) \\
11(3 \cdot 1 \%)\end{array}$ & $\begin{array}{r}11(3.5 \%) \\
5(1.4 \%)\end{array}$ & $\begin{array}{r}13(4 \cdot 1 \%) \\
8(2 \cdot 2 \%)\end{array}$ & $\begin{array}{l}2(0.6 \%) \\
5(1.4 \%)\end{array}$ \\
\hline Total & 669 & $48(7 \cdot 2 \%)$ & $27(4.0 \%)$ & $16(2.4 \%)$ & $21(3.2 \%)$ & $7(1.0 \%)$ \\
\hline
\end{tabular}

TABLE III-Incidence of Wound Infection with Staph. pyogenes and Intestinal Organisms after Potentially Dirty Operations

\begin{tabular}{|c|c|c|c|c|c|c|}
\hline \multirow[t]{2}{*}{ Ward } & \multirow{2}{*}{$\begin{array}{l}\text { No. of } \\
\text { Patients }\end{array}$} & \multirow{2}{*}{$\begin{array}{l}\text { Wound } \\
\text { Infections }\end{array}$} & \multicolumn{2}{|c|}{$\begin{array}{l}\text { St uph. pyogenes } \\
\text { Infection }\end{array}$} & \multicolumn{2}{|c|}{$\begin{array}{l}\text { Intestinal Organism } \\
\text { Infection }\end{array}$} \\
\hline & & & All & Major & All & Major \\
\hline $\begin{array}{l}\text { Old } \\
\text { New }\end{array}$ & $\begin{array}{l}179 \\
152\end{array}$ & $\begin{array}{l}67(37.4 \%) \\
30(19.7 \%)\end{array}$ & $\begin{array}{l}26(14.5 \%) \\
14(9 \cdot 2 \%)\end{array}$ & $\begin{array}{r}19(10 \cdot 6 \%) \\
5(3.3 \%)\end{array}$ & $\begin{array}{l}41(22.9 \%) \\
16(10.5 \%)\end{array}$ & $\begin{array}{l}22(12.3 \%) \\
10(6.6 \%)\end{array}$ \\
\hline Total & 331 & $97(29 \cdot 3 \%)$ & $40(12 \cdot 1 \%)$ & $24(7 \cdot 3 \%)$ & $57(17 \cdot 2 \%)$ & $32(9 \cdot 7 \%)$ \\
\hline
\end{tabular}


TABLE IV-Incidence of Primary and Secondary Staphylococcal Wound Infection after Clean and Potentially Dirty Operations in Old and New Environments

\begin{tabular}{|c|c|c|c|c|}
\hline Infection & $\begin{array}{l}\text { Type of } \\
\text { Operation }\end{array}$ & Old Ward & New Ward & Total \\
\hline \multirow[t]{2}{*}{ Primary } & $\left(\begin{array}{l}\text { Clean } \\
\text { Potentially Dirty }\end{array}\right.$ & $\begin{array}{ll}4 & (1 \cdot 3 \%) \\
3 & (1 \cdot 7 \%)\end{array}$ & $\begin{array}{ll}5 & (1.4 \%) \\
1 & (0.7 \%) \\
\end{array}$ & $\begin{array}{ll}9 & (1.3 \%) \\
4 & (1.2 \%) \\
\end{array}$ \\
\hline & Total & $7 \quad(1.4 \%)$ & $6 \quad(1 \cdot 2 \%)$ & $13(1 \cdot 3 \%)$ \\
\hline \multirow{2}{*}{ Secondary } & $\begin{array}{l}\text { Clean } \\
\text { Potentially Dirty }\end{array}$ & $\begin{array}{l}12(3 \cdot 8 \%) \\
23(12 \cdot 8 \%)\end{array}$ & $\begin{array}{rr}6 & (1 \cdot 7 \%) \\
13 & (8 \cdot 6 \%)\end{array}$ & $\begin{array}{l}18(2.7 \%) \\
36(10.9 \%)\end{array}$ \\
\hline & Total & $35(7 \cdot 1 \%)$ & $19(3.7 \%)$ & $54 \quad(5.4 \%)$ \\
\hline
\end{tabular}

TABLE V-Incidence of Primary and Secondary Major Staphylococcal Wound Infection after Clean and Potentially Dirty Operations in Old and New Environments

\begin{tabular}{|c|c|c|c|c|}
\hline Infection & $\begin{array}{l}\text { Type of } \\
\text { Operation }\end{array}$ & Old Ward & New Ward & Total \\
\hline \multirow[t]{2}{*}{ Primary } & $\left\{\begin{array}{l}\text { Clean } \\
\text { Potentially dirty }\end{array}\right.$ & $\begin{array}{ll}1 & (0.3 \%) \\
1 & (0.6 \%)\end{array}$ & $\begin{array}{ll}3 & (0.8 \%) \\
1 & (0.7 \%)\end{array}$ & $\begin{array}{ll}4 & (0.6 \%) \\
2 & (0.6 \%)\end{array}$ \\
\hline & Total & $2(0.4 \%)$ & $4(0.8 \%)$ & $6 \quad(0.6 \%)$ \\
\hline \multirow{2}{*}{ Secondary } & $\left\{\begin{array}{l}\text { Clean } \\
\text { Potentially dirty }\end{array}\right.$ & $\begin{array}{l}10(3.2 \%) \\
18(10.0 \%)\end{array}$ & $\begin{array}{ll}2 & (0.6 \%) \\
4 & (2.6 \%)\end{array}$ & $\begin{array}{ll}12 & (1.8 \%) \\
22 & (6.6 \%)\end{array}$ \\
\hline & Total & $28 \quad(5 \cdot 7 \%)$ & $6 \quad(1 \cdot 2 \%)$ & $34(3.4 \%)$ \\
\hline
\end{tabular}

TABLE VI-Incidence of Secondary and Major Type 84/85/- Staphylococcal Infections after Clean and Potentially Dirty Operations in the Old and New Environments

\begin{tabular}{|c|c|c|c|c|c|}
\hline \multirow{2}{*}{ Ward } & \multirow{2}{*}{$\begin{array}{l}\text { Type of } \\
\text { Operation }\end{array}$} & \multirow{2}{*}{$\begin{array}{l}\text { Staphylo- } \\
\text { coccal } \\
\text { Infections }\end{array}$} & \multicolumn{3}{|c|}{ Type $84 / 85 /-$ Infections } \\
\hline & & & All & Major & $\begin{array}{l}\text { Secondary } \\
\text { Major }\end{array}$ \\
\hline \multirow{2}{*}{ Old } & $\int \begin{array}{l}\text { Clean } \\
\text { Potentially dirty }\end{array}$ & $\begin{array}{l}16 \\
26\end{array}$ & $\begin{array}{r}9 \\
14\end{array}$ & $\begin{array}{r}7 \\
12\end{array}$ & $\begin{array}{r}6 \\
12\end{array}$ \\
\hline & Total & 42 & $23(54 \cdot 8 \%)$ & $19(45 \cdot 2 \%)$ & $18(42 \cdot 9 \%)$ \\
\hline \multirow{2}{*}{ New } & $\left\{\begin{array}{l}\text { Clean } \\
\text { Potentially dirty }\end{array}\right.$ & $\begin{array}{l}11 \\
14\end{array}$ & $\overline{3}$ & $\overline{1}$ & $=$ \\
\hline & Total & 25 & $3(12.0 \%)$ & $1(4 \cdot 0 \%)$ & - \\
\hline
\end{tabular}

dirty than after clean operations, in both the new and the old environment.

The infection rates, however regarded, were lower after the move to the new unit. The incidence of both staphylococcal and intestinal organism infection was considerably reduced, the most striking fall being in major staphylococcal infection after both clean and potentially dirty operations. Differences in the intestinal organism infection rate after clean operations were not significant, the numbers being small (Table II). Intestinal organism infection after potentially dirty operations is usually attributed to endogenous contamination, which is unlikely to be influenced by a move from one ward to another. There was, however, a fall in the incidence both of total infection with intestinal organisms and of major infection of this type after potentially dirty operations in the new ward (Table III). As explained in Part I, there is a possibility that some of these "autogenous" infections are examples of cross infection with intestinal organisms.

Staphylococcal infections were subdivided into a primary and a secondary group, as described. Only 13/67 (19.4\%) of all staphylococcal infections were classified as primary, $9 / 669$ $(1.3 \%)$ being after clean operations and $4 / 331(1.2 \%)$ after potentially dirty procedures (Table IV). When the incidence of primary staphylococcal infection was compared in the old and the new environments no great difference was found (Table IV). There was, however, an obvious fall in the incidence of secondary staphylococcal sepsis in the new ward, this being true for both clean and potentially dirty operations. This fall represented largely a reduction in major infections, after clean operations from 10 in the old ward to only two in the new, while, after potentially dirty operations, there was a similar fall from 18 to 4 (Table V). These differences in the incidence of major infection were offset by a slight increase in the incidence of minor secondary infections in the new ward.

A total of 26 postoperative wound infections gave a culture of a type 84/85/-Staph. pyogenes. In the old ward $23 / 42$ $(54.8 \%)$ of the staphylococcal infections were of this kind, while in the new ward $3 / 25(12.0 \%)$ were associated with the type $84 / 85 /$-penicillin-insensitive Staph. pyogenes (Table VI). Further, 19/23 of these infections in the old ward were classified as major sepsis as opposed to $1 / 3$ in the new ward. It is of interest that $18 / 19$ major infections giving a growth of type $84 / 85 /-$ Staph. pyogenes were classified as secondary in the old environment. In the new ward, however, the only major infection (type 84/85/-) was found to be primary, there being no case of major secondary staphylococcal sepsis due to this organism (Table VI).

\section{Discussion}

In this study similar groups of patients have been investigated in some detail, all having undergone operation involving an incision through clean prepared skin. From the information available regarding the bacteriological status of the wound environment in the operating theatre it seems that the ward has been the site of major improvement with the change of environment (Davidson et al., 1970).

The present concept of secondary infection was introduced in an attempt to define wound sepsis arising as a result of cross-infection in the ward, as opposed to primary infections arising from contamination either of an endogenous kind or from the operating theatre environment. Primary staphylococcal infections have been shown to occur in patients who were carriers of Staph. pyogenes either in their anterior nares or on the skin. It is not surprising that there was no difference in the incidence of autogenous staphylococcal infection in the two groups of patients. Staphylococcal contamination from the operating theatre environment, also classified as primary sepsis, was infrequent in both groups, this finding being supported by the results of settle-plate cultures and of plates taken from wounds at the end of operation (Davidson et al., 1970).

Differences in the pattern of secondary infection seem to confirm that the new ward environment had a beneficial effect in reducing the hazard of staphylococcal cross-infection. The phage type 84/85/-Staph. pyogenes responsible for much of the total ward staphylococcal cross-infection in the old unit gradually disappeared from the new ward environment (Part I). Probably the fall in incidence of all major secondary staphylococcal wound sepsis was at least in part due to the design and facilities in the new environment, this in turn being associated with the much less frequent finding of the ward staphylococcus type 84/85/-.

\section{Conclusions}

A considerable reduction in the incidence of wound infection has occurred in a surgical unit with $40 \%$ of its patient accommodation as single rooms and all under controlled ventilation. These modifications appear to have contributed significantly to the reduction of wound sepsis, but as adequate ventilation requires a high degree of division of wards into compartments it was not possible to say which was the more important. Furthermore, the planned bed complement has remained constant since the ward opened, hard architectural fact having successfully discouraged any temptation to "put-up" extra beds. It is not suggested that the reduced incidence of wound $F$ infection can be explained entirely by improvements in ward design and ventilation control, since by the nature of this experiment many uncontrolled or unknown factors could also have been in operation. Moreover, we know that new phage 


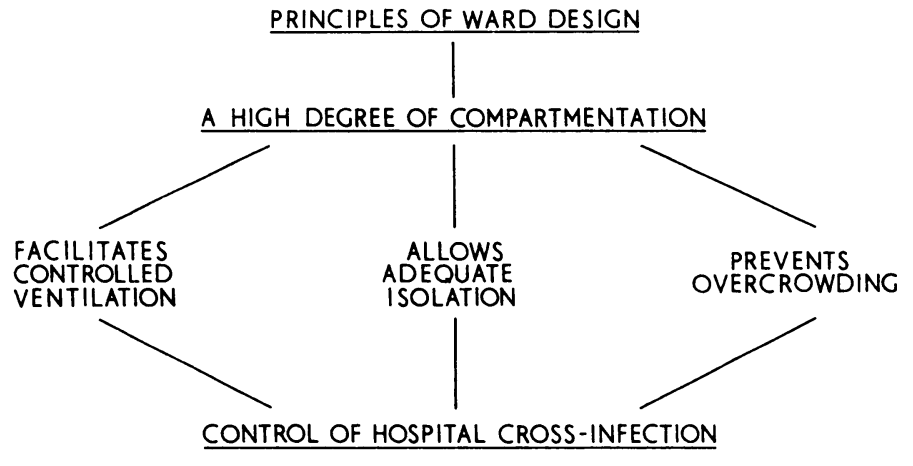

FIG. 1-Principles of surgical ward design. together in Fig. 1; all relate to control of hospital cross-infection. At a conference on this subject held some years ago Sir James Howie stated that there were no quick and facile answers to the problem and that administrative authorities might have to be prepared to make some expensive mistakes. This meant, he said, that new hospital accommodation might have to be built, with a still incomplete appreciation of all the factors involved in infection control (Conference Report, 1961). The new surgical unit in Aberdeen has been expensive, but, taking all results into account, perhaps not a mistake.

Substantial grant support for this study was made (to A. M. and G. S.) from the Secretary of State's (Scotland) Fund. This support is gratefully acknowledged.

We also wish to thank Mr. John Brand for considerable technical help.

\section{References}

Conference Report (1961). Hospital Bulletin, 19, 56.

Davidson, A. I. G (1969) Ph D Thesis Aberdeen University.

Davidson, A. I. G., Smylie, H. G., and Smith, G. (1970). British fournal of

Surgery. In press.
Smylie, H. G. (1960). M.D. Thesis, Aberdeen University.

Williams, R. E. O. Blowers, R, Garrod, L. P and Shooter, R. A. (1966)

Hospital Infection: Causes and Prevention, 2nd edn. London, Lloyd-Luke.

\title{
A Within-patient Comparison of Debrisoquine and Methyldopa in Hypertension
}

\author{
A. HEFFERNAN, A. CARTY, K. O'MALLEY, J. BUGLER
}

British Medical fournal, 1971, 1, 75-78

\section{Summary}

In a titrated dose cross-over trial of debrisoquine and methyldopa in 38 hypertensive patients neither drug was superior in lowering supine or standing diastolic pressure with a minimum of side effects. Methyldopa caused significantly greater reduction of supine $(P<0.001)$ and standing $(P<0.02)$ systolic pressure but caused intolerable side effects in two patients. Tiredness was the most characteristic and troublesome side effect with methyldopa and postural hypotension was prominent in patients while on debrisoquine.

\section{Introduction}

Our initial studies with debrisoquine showed that it is an effective antihypertensive agent with a relatively low incidence of side effects (Heffernan and Carty, 1970). To date no formal comparative clinical trial between debrisoquine and other sympathetic blocking agents has been carried out. A within-patient comparison of debrisoquine and methyldopa with some modifications was designed along the lines established by Prichard, Johnston, Hill, and Rosenheim (1968)

Mater Misericordiae Hospital, Dublin

A. HEFFERNAN, M.D., M.SC., Lecturer in Medicine (Present address : St. Vincent's Hospital, Dublin)

A. CARTY, M.B., M.R.C.P.I., Medical Tutor

A. CARTY, M.B., M.R.C.P.I., Medical Tutor ment of Therapeutics, University of Dundee)

J. BUGLER, M.B., B.CH., Registrar

\section{Patients and Methods}

Each patient had a "run-in" period on each drug during which the dosage was increased to give the desired reduction of blood pressure with no or with tolerable side effects. There followed a three-month period of assessment before the patient changed to the other drug. The order of administration of the two drugs under trial was randomized. The commercially available tablets of debrisoquine $10 \mathrm{mg}$ and methyldopa $250 \mathrm{mg}$ were used in a three times daily routine. Hydrochlorothiazide with potassium was added if blood pressure control was not satisfactory with the primary drug alone. At the end of each period of assessment patients were questioned directly about specific side effects, but those side effects complained of spontaneously by patients at intermediate visits were also recorded.

At the beginning of the trial a range of standing diastolic pressure was chosen which would be regarded as satisfactory control for each patient. For most of our patients the range $90-99 \mathrm{~mm} \mathrm{Hg}$ was selected, but a target of $80-89 \mathrm{~mm} \mathrm{Hg}$ was set for those with uncomplicated hypertension who were under 45 years old. Levels not more than $10 \mathrm{~mm} \mathrm{Hg}$ above the chosen range were regarded as fair control, but inability to maintain even fair control or the occurrence of intolerable side effects was regarded as a failure of treatment.

Blood pressure was measured by one of us (A.C., K.O.'M, or J.B.) on the London School of Hygiene and Tropical Medicine sphygmomanometer (Rose, Holland, and Crowley, 1964). Pressure was measured one minute and three minutes after lying down and one minute after standing up. Only the three-minute supine and the standing pressures were analysed. These physicians had no record of previous readings or of the drug being taken by the patient at the time. The physician (A.H.) who supervised the clinical care of the patients and adjusted dosage had all this information. 